medRxiv preprint doi: https://doi.org/10.1101/2020.11.17.20223701; this version posted November $19,2020$. The copyright holder for this preprint (which was not certified by peer review) is the author/funder, who has granted medRxiv a license to display the preprint in It is made available under a CC-BY-NC-ND 4.0 International license .

\title{
Effects of ambient air pollution on emergency room visits of children for acute respiratory
}

\section{symptoms}

Rashmi Yadav ${ }^{1 \#}$, Aditya Nagori ${ }^{2,3 \#}$, Aparna Mukherjee ${ }^{1}$, Varinder Singh ${ }^{4}$, Rakesh Lodha ${ }^{*}$, Sushil Kumar Kabra ${ }^{*}$ and Air pollution study group

Air pollution study group (alphabetical order) Geetika Yadav ${ }^{5}$, Jitendra Kumar Saini ${ }^{6}$, Kamal K. Singhal ${ }^{2}$, Kana Ram Jat ${ }^{1}$, Karan Madan $^{7}$, Mohan P George $^{8}$, M Kalaiwani $^{9}$, Parul Mrigpuri ${ }^{10}$, Raj Kumar ${ }^{10}$, Randeep Guleria ${ }^{7}$, Ravindra Mohan Pandey ${ }^{9}$, Rohit Sarin ${ }^{6}$, Rupinder Singh

Dhaliwal $^{5}$

\#Equal contribution, *Corresponding Author

\section{Affiliations}

${ }^{1}$ Department of Pediatrics, All India Institute of Medical Sciences, New Delhi-110029, India;

${ }^{2}$ CSIR-Institute of Genomics and Integrative Biology, New Delhi-110007, India;

${ }^{3}$ Academy of Scientific and Innovative Research (AcSIR), Ghaziabad- 201002, India

${ }^{4}$ Kalawati Saran Children Hospital and Lady Harding Medical College, New Delhi-110001, India;

5 Indian Council of Medical Research, New Delhi-110029 India

${ }^{6}$ National Institute of Tuberculosis and Respiratory Diseases, New Delhi-110030, India;

${ }^{7}$ Pulmonology, critical Care and Sleep disorders, All India Institute of Medical Sciences, New Delhi10029, India

${ }^{8}$ Delhi Pollution Control Committee, Kashmere Gate, New Delhi-110006, India;

${ }^{9}$ Department of Biostatistics, All India Institute of Medical Sciences, New Delhi-110029 India

${ }^{10}$ Vallabhbhai Patel Chest Institute; New Delhi-110007 India; 
medRxiv preprint doi: https://doi.org/10.1101/2020.11.17.20223701; this version posted November 19,2020 . The copyright holder for this preprint (which was not certified by peer review) is the author/funder, who has granted medRxiv a license to display the preprint in It is made available under a CC-BY-NC-ND 4.0 International license .

\begin{abstract}
Background: Data on the relation between the increase in ambient air pollution and acute respiratory illness in children are scarce. The present study aimed to explore the association between daily ambient air pollution and daily emergency room (ER) visits due to acute respiratory symptoms in children of Delhi.
\end{abstract}

Methods: In this epidemiological study, the daily counts of ER visits (ERV) of children $(\leq 15$ years) having acute respiratory symptoms from $1^{\text {st }}$ June 2017 to $28^{\text {th }}$ February 2019 were obtained from two general hospitals of Delhi. Simultaneously, data on daily average concentrations of particulate matter $\left(\mathrm{PM}_{10}\right.$ and $\left.\mathrm{PM}_{2.5}\right)$, nitrogen dioxide $\left(\mathrm{NO}_{2}\right)$, sulphur dioxide $\left(\mathrm{SO}_{2}\right)$, carbon monoxide $(\mathrm{CO})$, and ozone $\left(\mathrm{O}_{3}\right)$, and weather variables were provided by Delhi Pollution Control Committee from their four continuous ambient air quality monitoring stations. We used K-means clustering with time-series approach to derive pollutant-derived clusters and the study period was categorized into high, moderate and low air pollution days. The combined effect of these air pollutants on acute respiratory ERV was assessed. Multi-pollutant generalized additive models (GAM) with Poisson link function was used to estimate the 0-6 day lagged change in daily ER visits with the change in multiple pollutants levels, adjusting for weather variables, days of the week and public holidays.

Results: In 21 months, 132,029 children were screened at the ER of the participating hospitals. Of these 19,320 (14.6\%) were eligible, and 19120 were enrolled with complete data collection. The study period could be divided into 3 pollutant-derived clusters with high (Cluster 1, 150 days), moderate (Cluster 2, 204 days) low (Cluster 3, 284 days) levels of air pollution. There was a $28.7 \%$ and $21 \%$ increase in ERV among children respectively, on high and moderate level pollution days (Cluster 1 and 2) compared to low pollution days (Cluster 3) on the same day of exposure to air pollutants. Similar results were found when the exposure to ambient air pollution of previous 1-6 days were taken into account. GAM analysis showed that the association of the 
medRxiv preprint doi: https://doi.org/10.1101/2020.11.17.20223701; this version posted November 19, 2020. The copyright holder for this preprint (which was not certified by peer review) is the author/funder, who has granted medRxiv a license to display the preprint in It is made available under a CC-BY-NC-ND 4.0 International license .

acute respiratory ER visits with every 10 unit change of $\mathrm{PM}_{10}, \mathrm{NO}_{2}, \mathrm{O}_{3}, \mathrm{CO}$ and $\mathrm{SO}_{2}$ remained significant after adjusting for multi-pollutant and confounding variables effects. In contrast, no effect was seen for $\mathrm{PM}_{2.5}$. The ERVs for acute respiratory symptoms rose with increase in pollutants and the trends showed a percentage change $(95 \% \mathrm{CI}) 1.07 \%(0.32,1.83)$ increase in ERVs for an increase of 10 micrograms per cubic meter of $\mathrm{NO}_{2}$ at previous day $1,36.89 \%$ $(12.24,66.95)$ for 10 milligrams per cubic meter of $\mathrm{CO}$ at previous day 3 , and $12.77 \%(9.51$, 16.12) for 10 micrograms per cubic meter of $\mathrm{SO}_{2}$ at same day while decrease of $-0.18 \%(-0.32,-$ $0.03)$ for 10 micrograms per cubic meter of $\mathrm{PM}_{10}$ at same day, and $-4.16 \%(-5.18,-3.13)$ for $\mathrm{O}_{3}$ at previous day 3 .

Conclusion: An increase in the daily ER visits of children for acute respiratory symptoms was seen for 1-6 days after increase in daily ambient air pollution levels in Delhi.

Keywords: Ambient air quality, Air pollution, Asthma, Pneumonia, Children, Delhi

\section{Abbreviations}

PM: Particulate matter

$\mathrm{NO}_{2}$ Nitrogen dioxide

$\mathrm{SO}_{2:}$ Sulphur dioxide

CO: Carbon monoxide

$\mathrm{O}_{3}$ : Ozone

ER: Emergency room

AIIMS: All India Institute of Medical Science

KSCH: Kalawati Saran Children Hospital

AQI: Air quality index

INAQS: Indian National Air Quality Standards

GAM: Generalized-additive model 
medRxiv preprint doi: https://doi.org/10.1101/2020.11.17.20223701; this version posted November 19,2020 . The copyright holder for this preprint (which was not certified by peer review) is the author/funder, who has granted medRxiv a license to display the preprint in It is made available under a CC-BY-NC-ND 4.0 International license .

\section{Introduction}

Air pollution is among the leading environmental risk factors contributing to the global and regional burden of diseases in India (Khilnani \& Tiwari, 2018). Delhi is one of the most airpolluted cities in the world with highest annual mean particulate matter $(\mathrm{PM})_{2.5}$ levels of $209 \cdot 0 \mu \mathrm{g} / \mathrm{m}^{3}$ reported in the year 2017 (India State-Level Disease Burden Initiative Air Pollution Collaborators, 2018). Children due to their rapidly growing lungs, developing immune system, the pattern of ventilation, and outdoor activity are highly sensitive to the adverse effects of air pollution (H. Chen \& Goldberg, 2009; Z. Chen et al., 2015). Children with pre-existing chronic respiratory diseases are at potentially higher risk (L. Liu et al., 2009; Segala et al., 1998). Evidence suggests that ambient air pollutants' mixture including particulate matter $(\mathrm{PM})_{10}$, $\mathrm{PM}_{2.5}$, nitrogen dioxide $\left(\mathrm{NO}_{2}\right)$, sulphur dioxide $\left(\mathrm{SO}_{2}\right)$, carbon monoxide $(\mathrm{CO})$, and ozone $\left(\mathrm{O}_{3}\right)$ have adverse respiratory health outcomes in children. These include an increase in respiratory symptoms, decreased lung function (Qian et al., 2004), increased airway inflammation (Cassino et al., 1999), aggravated asthma and chronic lung disease (FINAL-REPORT_AQI_.Pdf, n.d.). Several cross-sectional studies on acute effects of ambient air pollution have been comprehensivelydone in Europe, America and some of the Asian countriesviz. China, South Korea, etc. These studies have reported a positive association between ambient air pollution exposure and increase in respiratory symptoms (Preutthipan et al., 2004), daily non-accidental mortality (Cropper et al., 1997), cardio-respiratory morbidity (Rodríguez-Villamizar et al., 2018; Tapia et al., 2019), and mortality (R. Chen et al., 2012), hospitalizations (Lu et al., 2019), and emergency room (ER) visits (Babin et al., 2007; G. Chen, Li, et al., 2017; Khan et al., 2019; Pande et al., 2002). However, studies showing adverse health effects of air pollution from different parts of India are limited (Balakrishnan et al., 2011; Jayaraman \& Nidhi, 2008; Maji et al., 2018; Pande et al., 2002). 
medRxiv preprint doi: https://doi.org/10.1101/2020.11.17.20223701; this version posted November 19,2020 . The copyright holder for this preprint (which was not certified by peer review) is the author/funder, who has granted medRxiv a license to display the preprint in It is made available under a CC-BY-NC-ND 4.0 International license.

In Delhi, few studies have indicated the association of acute ambient air pollution with respiratory morbidity (Agarwal et al., 2006; Jayaraman \& Nidhi, 2008; Maji et al., 2018), respiratory mortality (Maji et al., 2017; Rajarathnam et al., 2011), and emergency visits for cardio-respiratory conditions (Pande et al., 2002). However, studies on acute effects of ambient air pollution on acute respiratory emergency visits are scarce. Therefore, we planned to study the impact of daily ambient air pollution on daily ER visits of children for acute respiratory symptoms in Delhi. In this work, we presented a comprehensive analysis to estimate the combined and individual effect of pollutants on pediatric ER visits in Delhi. We took a new unsupervised data-driven, machine learning approach to categorize days into bad, moderate and good air-quality days. This categorization acts as a proxy for the overall effect of pollutants from a single day which is further assessed for an increase in ER visits. We also looked at the individual impact of pollutants after adjusting for weather and holidays in single and multipollutant models.

\section{Material and methods}

\subsection{Data collection}

This cross-sectional study was carried out in Delhi from $1^{\text {st } J u n e ~} 2017$ to $28^{\text {th }}$ February 2019. Daily counts of ER visits to hospitals were collected from two hospitals of Delhi. All children $(\leq 15$ years) visiting the ER of the All India Institute of Medical Science (AIIMS) and Kalawati Saran Children Hospital (KSCH), were screened for acute onset (less than two weeks) of respiratory symptoms by a project staff nurse and enrolled in the study. The project staff nurses trained in data collection were posted in the ER, round the clock, $24 \times 7$ for the whole duration of the data collection period. The paediatrician on duty in the ER evaluated and managed the children. Children were included if they were: (i) residing in Delhi continuously for at least four weeks, and (ii) having acute onset ( $\leq 2$ weeks) of respiratory symptoms as well as those with exacerbations of chronic lung disease in the last two weeks. Children who were not available 
medRxiv preprint doi: https://doi.org/10.1101/2020.11.17.20223701; this version posted November 19,2020 . The copyright holder for this preprint (which was not certified by peer review) is the author/funder, who has granted medRxiv a license to display the preprint in It is made available under a CC-BY-NC-ND 4.0 International license .

because of investigations or procedures and whose parents/ guardians did not consent to participate in the study were excluded from the study. After obtaining written informed consent from parents/ caretaker of eligible children the demographics, diagnosis and clinical details were recorded by the staff nurse from the patient card in the study proforma.

During the study period, daily average air pollution data from 4 continuous ambient air quality monitoring stations (CAAQMS) located in Anand Vihar, Mandir Marg, R.K. Puram, and Punjabi Bagh were obtained. Daily 24-hourly average concentrations ofPM $\mathrm{PM}_{10}, \mathrm{PM}_{2.5}, \mathrm{NO}_{2}, \mathrm{SO}_{2}$, $\mathrm{CO}$, three 8-hourly concentrations of $\mathrm{O}_{3}$, daily mean temperature, and relative humidity data were collected from Delhi Pollution Control Committee.

The Institutional Review Boards approved the study protocol at respective institutions [AIIMS Institute ethics committee (Ref IEC/88/09.12.2015, RP-22/2015) and KSCH (LHMC/ECHR/2016/02)]. Written informed consent was obtained from the parent/guardian of the participants.

\subsection{Statistical Analysis}

The cumulative effect of daily concentration of all the six air pollutants on the proportion of ER visits due to acute respiratory symptoms $\leq$ two weeks amongst and target population was assessed by deriving pollutant derived clusters days. K-means clustering 'a machine learning algorithm' was performed on the air pollutant variables to divide the study period into higher, moderate and low air pollutant days (Jin \& Han, 2010; Sinha et al., 2017). The average city values of 6 ambient air pollutants acquired from 4 CAAQMS of Delhi were used. The clusters were derived based on breakpoints for Indian Air quality index (IAIQ) in the increasing order of severity for various pollutants according to Indian National Air Quality Standards (INAQS) given by Central Pollution Control Board in 2014 (Table 1)(FINAL-REPORT_AQI_.Pdf, n.d.; Kesavachandran et al., 2015). 
medRxiv preprint doi: https://doi.org/10.1101/2020.11.17.20223701; this version posted November 19,2020 . The copyright holder for this preprint (which was not certified by peer review) is the author/funder, who has granted medRxiv a license to display the preprint in It is made available under a CC-BY-NC-ND 4.0 International license .

Table 1: Air quality index categories and breakpoints for ambient air pollutants

\begin{tabular}{|c|c|c|c|c|c|c|}
\hline AQI Category (Range) & $\mathrm{PM}_{10}(24 \mathrm{hr})$ & $\mathrm{PM}_{2.5}$ (24hr) & $\mathrm{NO}_{2}(24 \mathrm{hr})$ & $\mathrm{O}_{3}(8 \mathrm{hr})$ & CO (8hr) & $\mathrm{SO}_{2}(24 \mathrm{hr})$ \\
\hline Good (0-50) & $0-50$ & $0-30$ & $0-40$ & $0-50$ & $0-1.0$ & $0-40$ \\
\hline Satisfactory (51-100) & $51-100$ & $31-60$ & $41-80$ & $51-100$ & $1.1-2.0$ & $41-80$ \\
\hline $\begin{array}{l}\text { Moderately polluted } \\
(\mathbf{1 0 1 - 2 0 0 )}\end{array}$ & $101-250$ & $61-90$ & $81-180$ & $101-168$ & $2.1-10$ & $81-380$ \\
\hline Poor (201-300) & $251-350$ & $91-120$ & $181-280$ & $169-208$ & $10-17$ & $381-800$ \\
\hline Very Poor (301-400) & $351-430$ & $121-250$ & $281-400$ & $209-748$ & $17-34$ & $801-1600$ \\
\hline Severe (401-500) & $430+$ & $250+$ & $400+$ & $748+$ & $34+$ & $1600+$ \\
\hline
\end{tabular}

The association of combined effect of ambient air pollutants levels for the same day (day 0) with the total daily ERVs and ERVs due to acute respiratory symptoms was calculated using a linear regression model. Daily percentage of enrolled children was calculated as (total daily number of enrolled children/ daily total number of children attended emergency room)*100. The percentage rise of children in high and moderate to air quality days cluster was compared to lower reference air quality day's cluster.

Time-series analysis was done to explore the delayed association between these outcomes considering exposure to the air pollutants on previous 1-6 days. Similarly, the association between the ambient air pollutants and percentage of total daily enrolled children with individual respiratory symptoms (cough, difficulty in breathing, nasal symptoms \& noisy breathing) on same days well as up to previous 1-6 days of exposure to pollutants was assessed. A generalizedadditive model (GAM) with the Poisson link function was used to evaluate the association between the change in daily 24 hourly average air pollutants concentration and 1) total daily number of children attending ER, and 2) percentage total daily enrolled children with acute respiratory symptoms. Single pollutant model was run to study the individual lag effect of each of 6 air pollutant variables on the daily numbers of ER visits of children. Data was analyzed on 
medRxiv preprint doi: https://doi.org/10.1101/2020.11.17.20223701; this version posted November 19,2020 . The copyright holder for this preprint (which was not certified by peer review) is the author/funder, who has granted medRxiv a license to display the preprint in It is made available under a CC-BY-NC-ND 4.0 International license .

daily timescale and accounted for the mean ambient temperature; mean relative humidity, day of the week, and public holidays. Smoothing spline function was applied to analyze the exposureresponse relationship between the log-relative respiratory morbidity and the pollutants levels. The effect of pollutants was analyzed for the same day of exposure to the pollutants and considering exposure to pollutants for previous 1-3 days (Darrow et al., 2014). A multi-pollutant model was used to study the lag effect of interaction among different pollutants. The multipollutant model was performed for the pollutants that were significant in single pollutant analysis, and the lag day that had the highest percentage change was estimated. The data were presented as the percentage changes with $95 \%$ confidence interval (CI) in the daily acute respiratory ER visits per $10 \mu \mathrm{g} / \mathrm{m}^{3}$ (except $10 \mathrm{mg} / \mathrm{m}^{3}$ for $\mathrm{CO}$ ) increase in all the pollutants concentration. All the analysis was performed using R-software version 3.6. (R: The R Project for Statistical Computing, n.d.).

\section{Results}

\subsection{Descriptive statistics}

During the study period, a total 1, 32,029 of children were screened who attended ER. Of these 19,320 children were eligible as they were having acute respiratory symptoms ( $\leq 2$ weeks) and residing in Delhi for the past four weeks (Figure1). Of those eligible, 19120 children were enrolled. 
medRxiv preprint doi: https://doi.org/10.1101/2020.11.17.20223701; this version posted November 19,2020 . The copyright holder for this preprint (which was not certified by peer review) is the author/funder, who has granted medRxiv a license to display the preprint in It is made available under a CC-BY-NC-ND 4.0 International license .

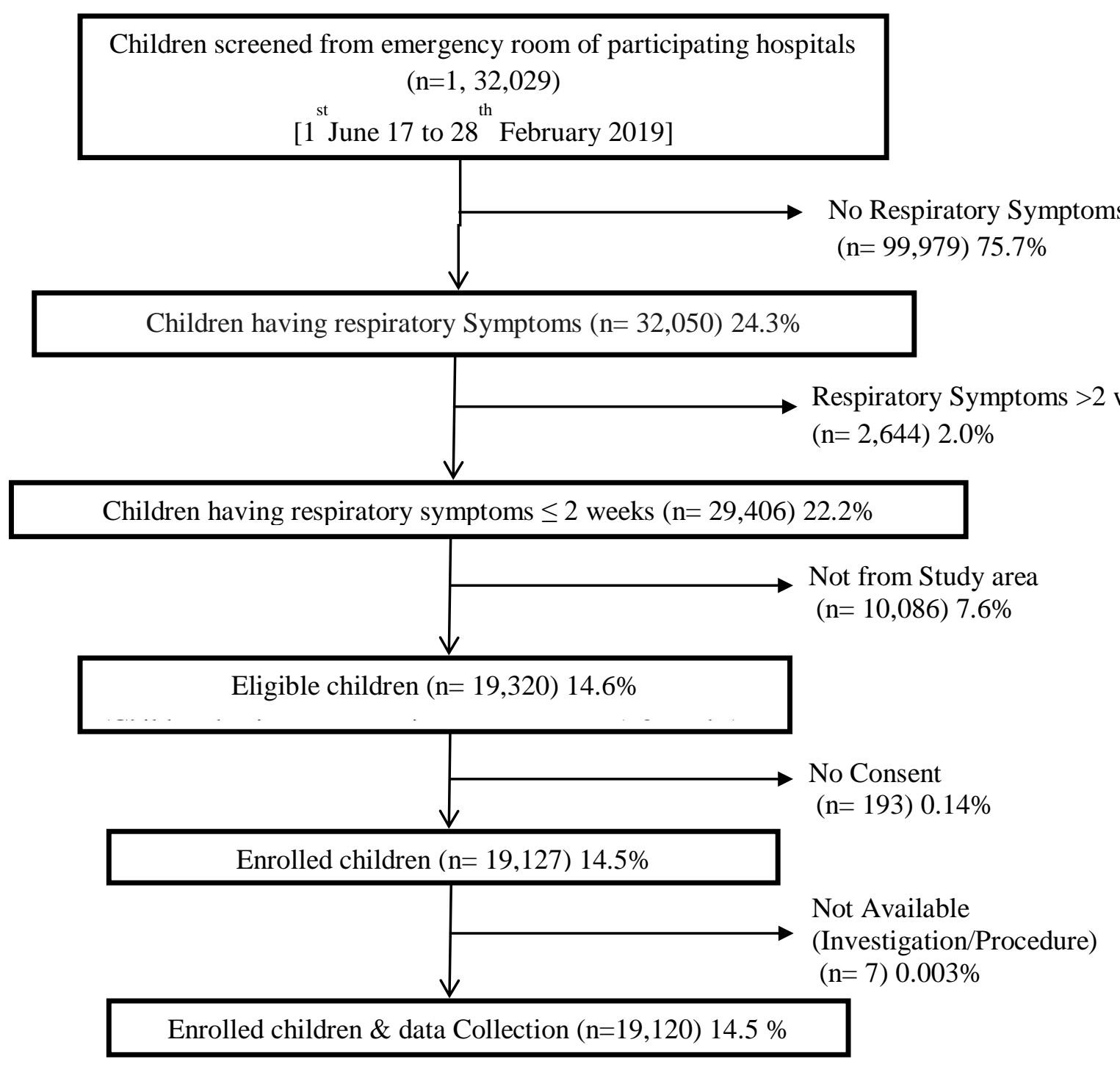

Figure 1: Screening and enrolment of children from emergency room of four participating hospitals during the study period

Demographic and clinical characteristics of enrolled children are shown in Table 2. The median (interquartile) age of the children was $1.1(0.5,3.0)$ years. Two-thirds of them were boys $(66 \%)$. Ninety-eight per cent of children had cough, $62 \%$ had noisy breathing, $84 \%$ had difficulty in breathing, and $83 \%$ reported nasal symptoms. The average duration of acute respiratory symptoms was four days. Among the enrolled children, $85 \%$ were given ambulatory treatment, $14 \%$ were advised admission, while $1 \%$ were referred to other departments. Almost all the households were using liquefied petroleum gas for daily cooking, while approximately $0.5 \%$ 
medRxiv preprint doi: https://doi.org/10.1101/2020.11.17.20223701; this version posted November 19, 2020. The copyright holder for this preprint (which was not certified by peer review) is the author/funder, who has granted medRxiv a license to display the preprint in It is made available under a CC-BY-NC-ND 4.0 International license.

used biomass or kerosene as the primary cooking fuel. The average number of household members was five withover a half living in 1-2 roomed houses. Of these, about $85 \%$ of households had a separate kitchen. Around $20 \%$ of children lived in homes where inmates regularly smoked.

Table 2: Characteristics of total daily enrolled children having acute respiratory symptoms ( $\leq 2$ weeks) and residing in Delhi for the past four weeks

\begin{tabular}{|c|c|c|}
\hline \multirow{2}{*}{$\begin{array}{l}\text { Parameters } \\
\text { Age }(\text { Mean } \pm \text { SD) }\end{array}$} & \multicolumn{2}{|c|}{ Total daily enrolled children $(\mathrm{n}=\mathbf{1 9 , 1 2 0})$} \\
\hline & & $2.5 \pm 1.6$ years \\
\hline Age ( Median, IQR) & & $\begin{array}{l}1.1(0.5,3.0) \\
\text { years }\end{array}$ \\
\hline \multirow[t]{2}{*}{$\operatorname{Sexn(\% )}$} & Male & $12706(66.5)$ \\
\hline & Female & 6414 (33.5) \\
\hline \multirow[t]{4}{*}{ Respiratory Symptoms n (\%) } & Cough & $18707(97.8)$ \\
\hline & Noisy Breathing & $11906(62.3)$ \\
\hline & Difficulty in Breathing & $16070(84.0)$ \\
\hline & Nasal Symptoms & $15911(83.2)$ \\
\hline Duration of Symptoms, days (Mean \pm SD) & & $3.5 \pm 1.9$ days \\
\hline Respiratory rate, per minute (Mean \pm SD) & & $46.7 \pm 6.8$ \\
\hline Chest indrawing, n (\%) & & $8552(25.7)$ \\
\hline Chest crepitations, n (\%) & & $9351(28.2)$ \\
\hline Chest rhonchi, n (\%) & & $14220(42.8)$ \\
\hline Oxygen saturation $(\%),($ Mean \pm SD $)$ & & $94.9 \pm 9.7$ \\
\hline \multirow[t]{5}{*}{ Outcomes at 12 hours, n (\%) } & Ambulatory treatment & $16328(85 \%)$ \\
\hline & Advised admission & $2706(14.15 \%)$ \\
\hline & $\begin{array}{l}\text { Referred to another } \\
\text { department }\end{array}$ & $146(0.76 \%)$ \\
\hline & Death & 0 \\
\hline & LAMA & 0 \\
\hline \multirow[t]{3}{*}{ Cooking fuel n (\%) } & Gas & $19026(99.5)$ \\
\hline & Biomass & $84(0.43)$ \\
\hline & Kerosene & $10(0.05)$ \\
\hline Households having separate kitchen n (\%) & & $16291(85.2)$ \\
\hline Smoker at home, n (\%) & & $3837(20.06)$ \\
\hline Total number of rooms (Median, IQR) & & $2(1,2)$ \\
\hline Total number of household members $($ Mean \pm SD) & & $4.9 \pm 2.2$ \\
\hline
\end{tabular}


medRxiv preprint doi: https://doi.org/10.1101/2020.11.17.20223701; this version posted November 19, 2020. The copyright holder for this preprint (which was not certified by peer review) is the author/funder, who has granted medRxiv a license to display the preprint in It is made available under a CC-BY-NC-ND 4.0 International license.

\subsection{Ambient mean monthly concentration of air pollutants over the study period}

The monthly trends of city average levels of six air pollutants varied during 21 months of the study period, as shown in Figure 2. From June 2017 to February 2019, two high peaks in air pollutants (a level depicting poor air quality) were observed during the months of October to December corresponding to the winter season. Another peak was found in June in the year 2018, which was possibly due to a heavy dust storm. During the summer season, (March to June) relatively low peaks of air pollutants were recorded showing moderate air quality in comparison to the winter season. The air quality was relatively satisfactory during the monsoon season from July to September.

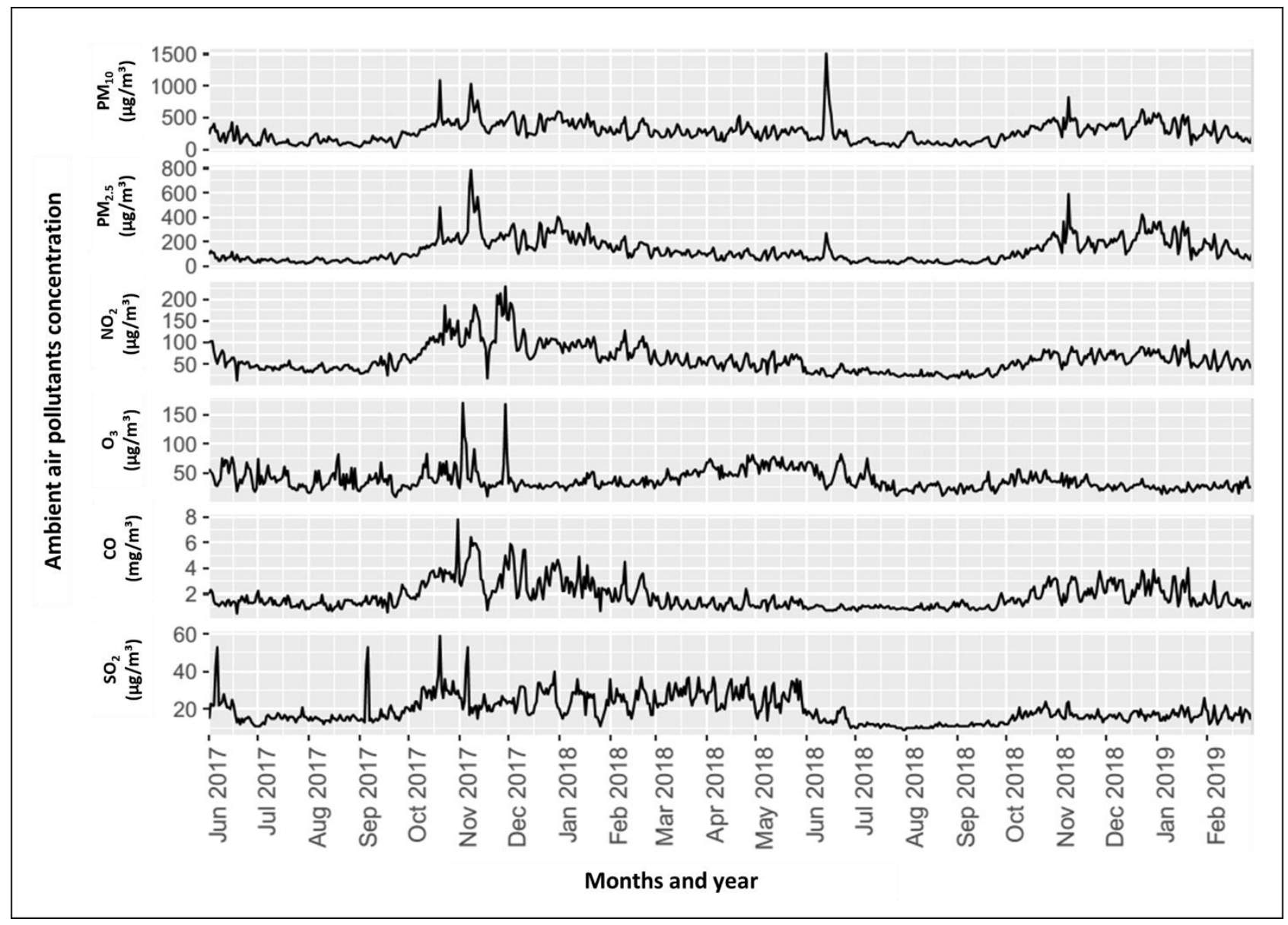

Figure 2: Mean monthly average levels of four pollutants during the study period (June 2017-February 2019) 
medRxiv preprint doi: https://doi.org/10.1101/2020.11.17.20223701; this version posted November 19, 2020. The copyright holder for this preprint (which was not certified by peer review) is the author/funder, who has granted medRxiv a license to display the preprint in

It is made available under a CC-BY-NC-ND 4.0 International license.

\subsection{Comparison of six pollutants levels between three clusters}

The entire study duration of 674 days was divided into three clusters based on AQI based sub-categories for individual air pollutants. The three pollutant derived clusters were significantly different from each other ( $\mathrm{p}<0.001$ for all the pollutants), except for $\mathrm{O}_{3}(\mathrm{p}=0.439)$.

Figure $3 \&$ Table 3 shows the summary statistics for six air pollutants viz. $\mathrm{PM}_{10}\left(\mu \mathrm{g} / \mathrm{m}^{3}\right), \mathrm{PM}_{2.5}$ $\left(\mu \mathrm{g} / \mathrm{m}^{3}\right), \mathrm{NO}_{2}\left(\mu \mathrm{g} / \mathrm{m}^{3}\right), \mathrm{O}_{3}\left(\mu \mathrm{g} / \mathrm{m}^{3}\right), \mathrm{CO}\left(\mathrm{mg} / \mathrm{m}^{3}\right)$, and $\mathrm{SO}_{2}\left(\mu \mathrm{g} / \mathrm{m}^{3}\right)$ (Figure 4) in each cluster. Cluster 1 comprises of 150 days having highest levels of pollutants, e.g. median (min.-max.) levels of $\mathrm{PM}_{10}$ was $449(355-1511) \mu \mathrm{g} / \mathrm{m}^{3}$. Cluster 2 includes 204 days with moderate levels of pollutants, e.g. median (min.-max.)levels of $\mathrm{PM}_{10} 284$ (165-1018) $\mu \mathrm{g} / \mathrm{m}^{3}$, and Cluster 3 includes 284 days with lowest levels of pollutants, e.g. median (min.-max.) levels of $134(32-349) \mu \mathrm{g} / \mathrm{m}^{3}$.

Table 3: Descriptive statistics of daily 24 hourly levels of ambient air pollutants inthe three pollutants-derived cluster days

\begin{tabular}{lccc}
\hline $\begin{array}{c}\text { Ambient air } \\
\text { pollutants }\end{array}$ & $\begin{array}{c}\text { Cluster 1 } \\
\text { Higher levels of } \\
\text { pollutants } \\
\text { (n days =150) }\end{array}$ & $\begin{array}{c}\text { Cluster 2 } \\
\text { Moderate levels of } \\
\text { pollutants } \\
\text { (n days = 204) }\end{array}$ & $\begin{array}{c}\text { Cluster 3 } \\
\text { Lower levels of } \\
\text { pollutants } \\
\text { (n days = 284) }\end{array}$ \\
\hline $\mathbf{P M}_{\mathbf{1 0}}\left(\boldsymbol{\mu g} / \mathbf{m}^{\mathbf{3}}\right)$ & $449(355-1511)$ & $284(165-1018)$ & $134(32-349)$ \\
\hline $\mathbf{P M}\left(\boldsymbol{\mu g} / \mathbf{m}^{\mathbf{3}}\right)$ & $264(145-787)$ & $134(69-242)$ & $51(19-91)$ \\
\hline $\mathbf{N O}_{\mathbf{2}}\left(\boldsymbol{\mu g} / \mathbf{m}^{\mathbf{3}}\right)$ & $97(22-230)$ & $62(12-103)$ & $38(16-82)$ \\
\hline $\mathbf{O}_{\mathbf{3}}\left(\boldsymbol{\mu g} / \mathbf{m}^{\mathbf{3}}\right)$ & $32(14-170)$ & $34(10-81)$ & $34(9-82)$ \\
\hline $\mathbf{C O}\left(\mathbf{m g} / \mathbf{m}^{\mathbf{3}}\right)$ & $3(1-8)$ & $1(0.4-3)$ & $1(1-2)$ \\
\hline $\mathbf{S O}\left(\boldsymbol{\mu g} / \mathbf{m}^{\mathbf{3}}\right)$ & $22(13-59)$ & $21(11-37)$ & $14(9-53)$ \\
\hline $\begin{array}{l}\text { Data expressed as median (minimum-maximum). } \\
\text { Abbreviations: PM-particulate matter, NO2-nitrogen dioxide, O3-ozone, CO-carbon monoxide, SO2-sulfur dioxide. }\end{array}$ \\
\hline
\end{tabular}




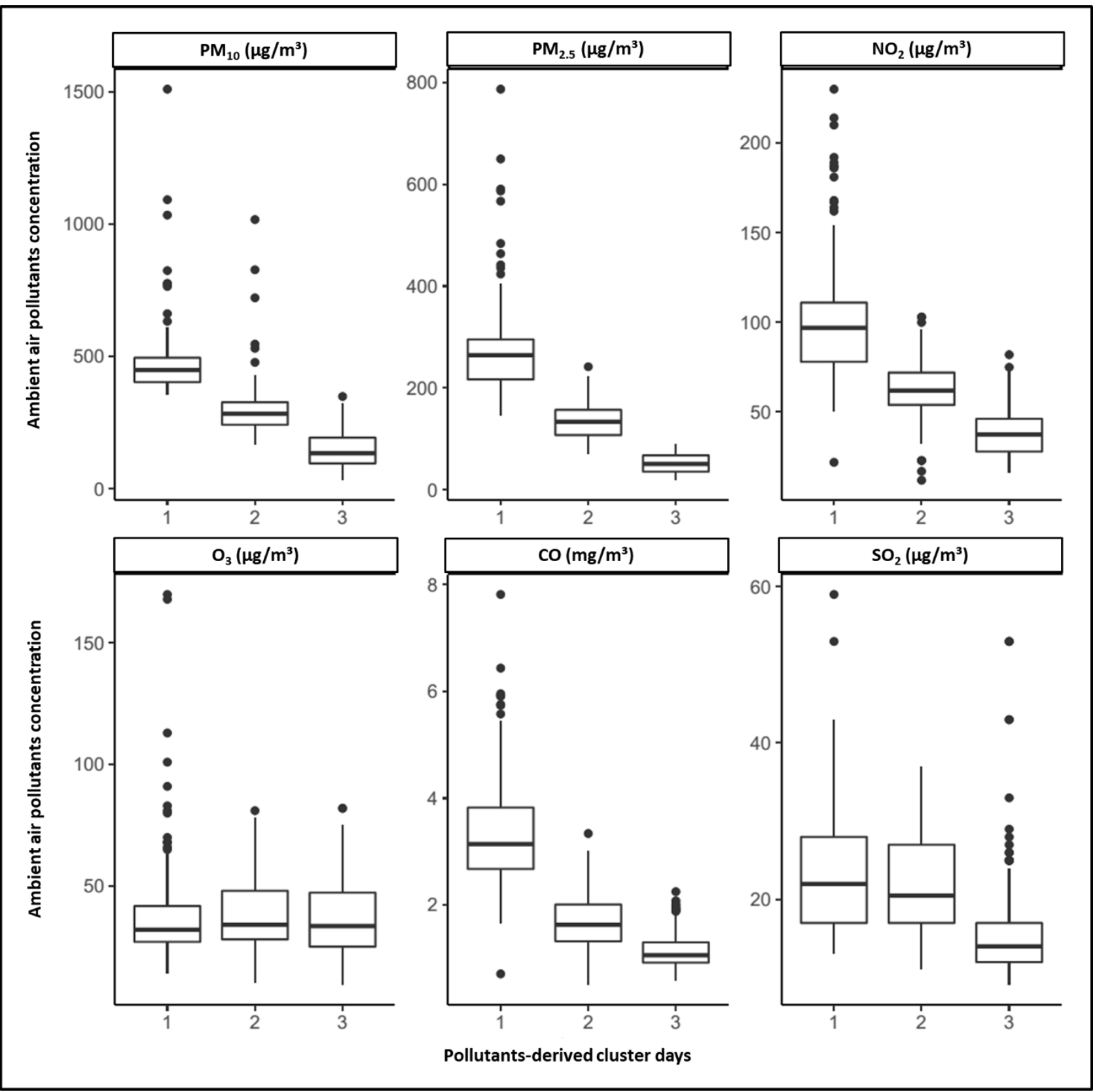

Figure 3: Box plot showing a comparison of each pollutant between the three pollutant-derived cluster days. Data are presented as box and whisker plots showing the median and interquartile range for air pollutants concentration. Pollutant-derived cluster days 1: higher levels of pollutants, cluster days 2: moderate levels of pollutants and cluster days 3: lower levels of pollutants. 
medRxiv preprint doi: https://doi.org/10.1101/2020.11.17.20223701; this version posted November 19, 2020. The copyright holder for this preprint (which was not certified by peer review) is the author/funder, who has granted medRxiv a license to display the preprint in It is made available under a CC-BY-NC-ND 4.0 International license.

\subsection{Association between ambient air pollutants and emergency room visits}

\subsubsection{Association between air pollution and daily total ERVs and ERVs due to acute respiratory illness among children}

Highest number of Total ER visits were recorded during low air pollution days in comparison to moderate and high pollution cluster days (Figure 4 a). On comparing the percentage of total enrolled children (representing children with acute respiratory symptoms $<2$ weeks among all children visiting ER and residing in Delhi), a significant difference was observed between the three clusters on the same day of exposure to the air pollution. There were a higher percentage of children in cluster 1 in comparison to cluster $2 \& 3$ (Figure 4 b).

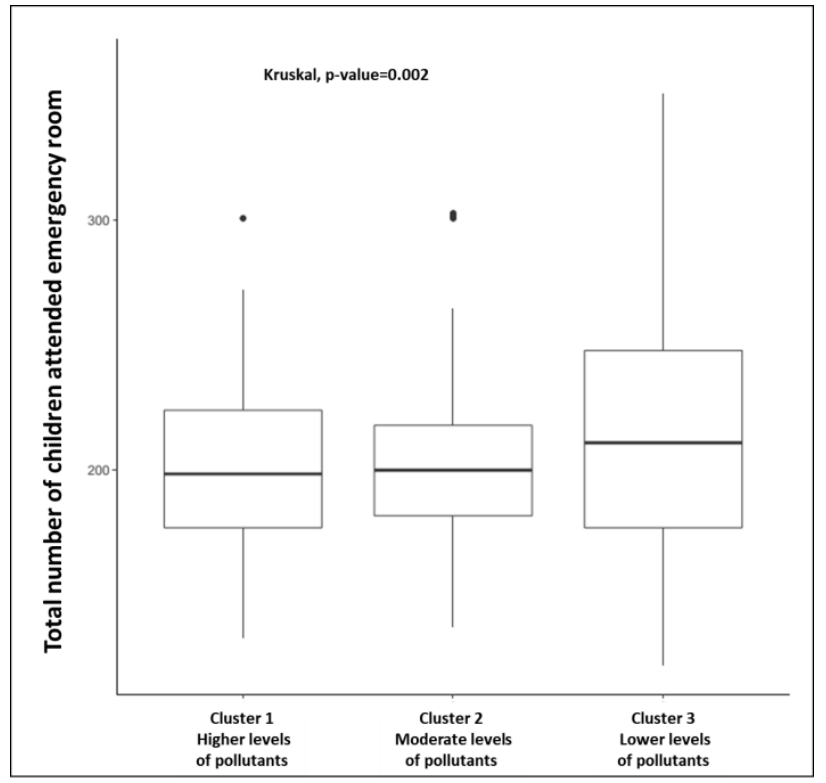

(a)

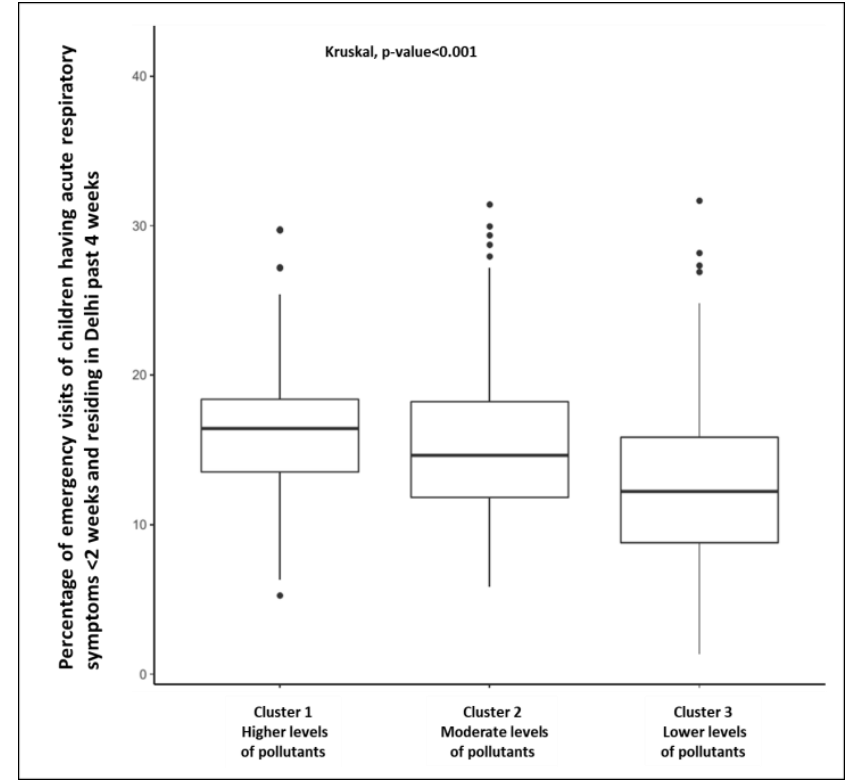

(b)

Figure 4: Comparison of (a) the total daily ERVs, and (b) daily ERVs due to acute respiratory symptoms between the three pollutant-derived cluster days. Data are presented as box and whisker plots showing median and interquartile range. Pollutant-derived cluster days presented as cluster 1: higher levels of pollutants, cluster 2: moderate levels of pollutants and cluster 3: lower levels of pollutants. 
medRxiv preprint doi: https://doi.org/10.1101/2020.11.17.20223701; this version posted November 19, 2020. The copyright holder for this preprint (which was not certified by peer review) is the author/funder, who has granted medRxiv a license to display the preprint in It is made available under a CC-BY-NC-ND 4.0 International license .

On the day of exposure, there was $28.73 \%$ increase in the proportion of children, having acute respiratory symptoms, enrolled daily from ER in cluster 1 and $20.96 \%$ in cluster 2 as compared to cluster 3 (Figure 5). Similar results were found when the trend of ERVs after exposure to ambient air pollution of previous 1-6 days was taken into account.

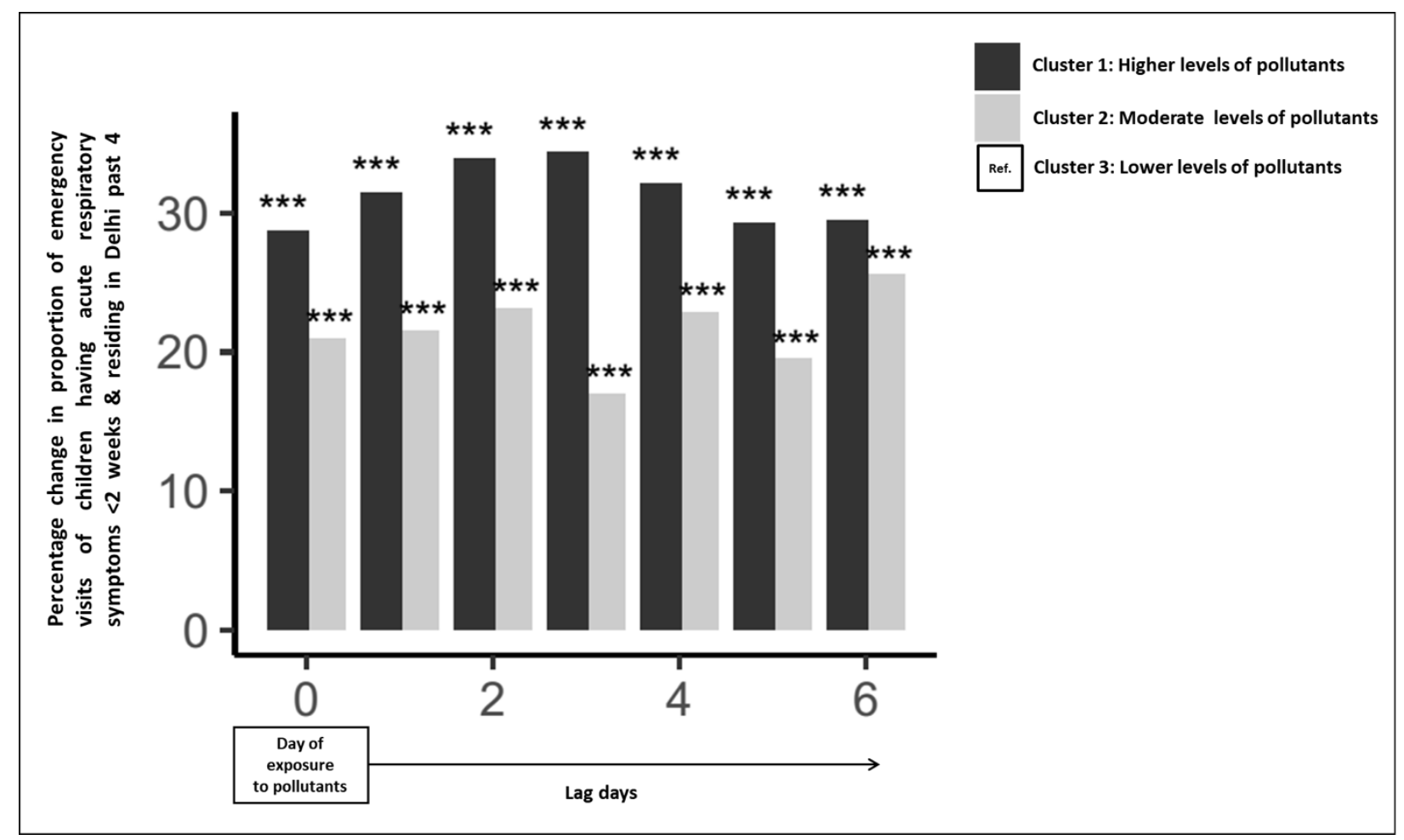

Figure 5: Percent increase in the proportion of total daily enrolled children attending ER with increasing air pollution [as compared with data from cluster 1]. ***p<0.0005 
medRxiv preprint doi: https://doi.org/10.1101/2020.11.17.20223701; this version posted November 19, 2020. The copyright holder for this preprint (which was not certified by peer review) is the author/funder, who has granted medRxiv a license to display the preprint in It is made available under a CC-BY-NC-ND 4.0 International license.

\subsubsection{Percent increase in the proportion of total dailyenrolled children with individual respiratory symptoms with increasing air pollution}

The proportion of the total daily enrolled children for individual respiratory symptoms that we recorded was compared, and the percentage change was quantified. On the day of exposure, the proportion of children enrolled with cough (Figure 6A), nasal symptoms (Figure 6B), noisy breathing (Figure 6C) and difficulty in breathing (Figure 6D) was high in both cluster 1 and cluster 2 as compared to the proportion of children enrolled in the cluster 3. A similar effect was noticed when the exposure to ambient air pollution of previous 1-6 days was taken into account.

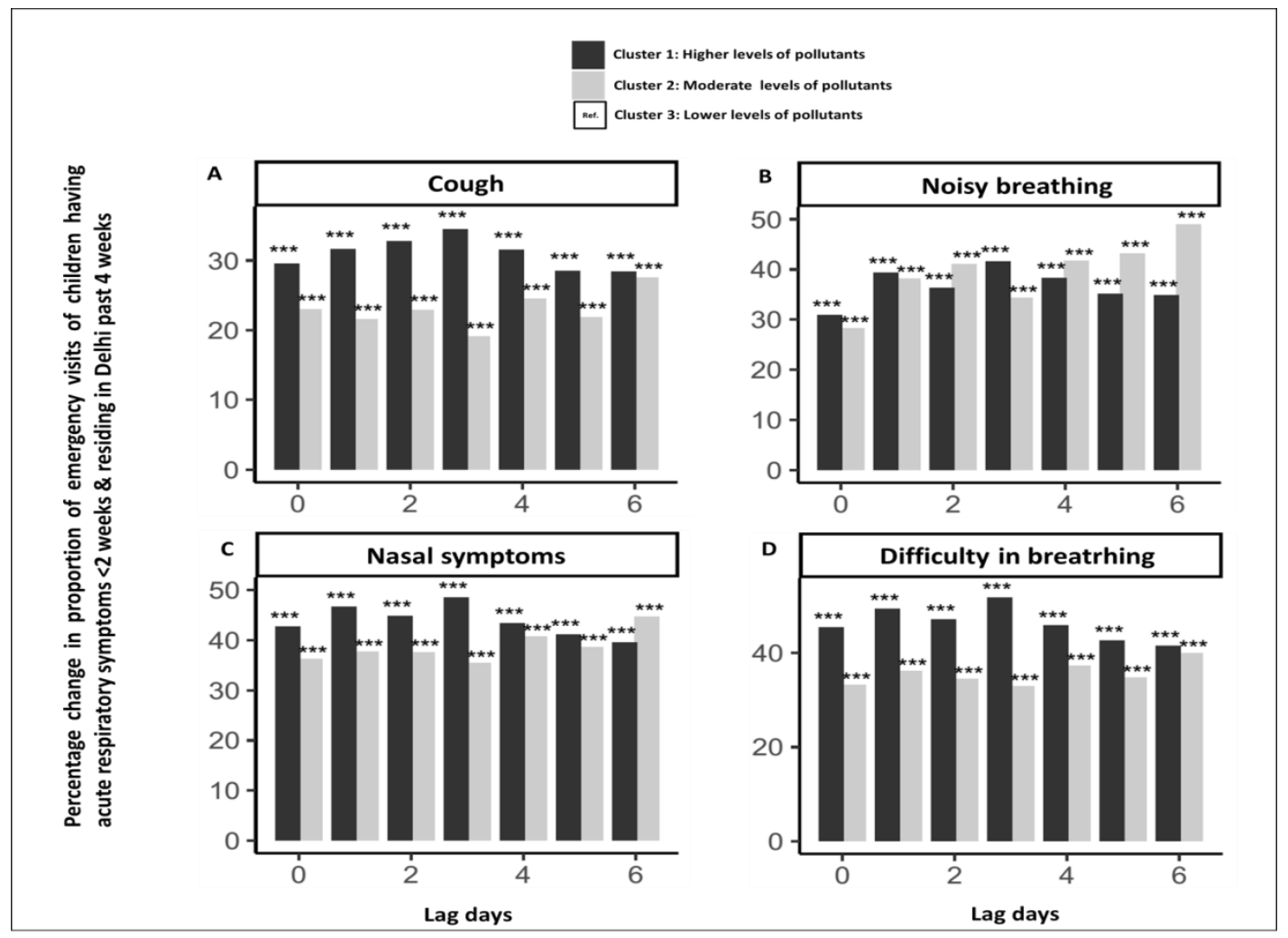

Figure 6: Comparison of percentage increase of the proportion of total daily enrolled children with individual respiratory symptoms for $<2$ weeks and residing in Delhi between the three pollutant-derived days clusters: A) Cough, B) nasal symptoms, C) noisy breathing, and D) difficulty in breathing. ${ }^{*} \mathrm{p}<0.05, * * \mathrm{p}<0.005, * * * \mathrm{p}<0.0005$. 
medRxiv preprint doi: https://doi.org/10.1101/2020.11.17.20223701; this version posted November 19, 2020. The copyright holder for this preprint (which was not certified by peer review) is the author/funder, who has granted medRxiv a license to display the preprint in It is made available under a CC-BY-NC-ND 4.0 International license.

\subsubsection{Effect of individual pollutants using a multi-pollutant generalized additive model onthe total daily number of children attended ER and children with acute respiratory symptoms visiting ER}

Results of the multi-pollutant models are shown in Table 4. Only the highest percentage change in ER visits of children identified from the single-pollutant model (supplementary Table 1) at a single lag day are presented. As shown in Table 4, the total daily number of children attended ER were found positively associated with $\mathrm{PM}_{10}, \mathrm{SO}_{2}$ on the same day and $\mathrm{CO}$ on previous day 2 of exposure to pollutants, while negatively associated with $\mathrm{PM}_{2.5}$ on the same day and $\mathrm{O}_{3}$ on previous day 3 of exposure to the pollutant. The association between total daily numbers of children visiting ER having acute respiratory symptoms with the change of $\mathrm{PM}_{10}, \mathrm{NO}_{2}, \mathrm{O}_{3}, \mathrm{CO}$ and $\mathrm{SO}_{2}$ was significant even after adjustment for multi-pollutant effects and confounders. However, the effect of $\mathrm{PM}_{2.5}$ could not be seen. Individual pollutants were found to be associated with ERvisits of children having individual respiratory symptoms such as cough, noisy breathing, and difficulty in breathing and nasal symptoms. 
medRxiv preprint doi: https://doi.org/10.1101/2020.11.17.20223701; this version posted November 19, 2020. The copyright holder for this preprint (which was not certified by peer review) is the author/funder, who has granted medRxiv a license to display the preprint in

Table 4. Percentage change in daily emergency visits of children per 10 -unit increase of pollutants at different lag days in the multi-pollutant model

\begin{tabular}{|c|c|c|c|c|}
\hline $\begin{array}{l}\text { Total daily } \\
\text { number of } \\
\text { children }\end{array}$ & Pollutant & Lag days & $\begin{array}{l}\text { Single pollutant model* } \\
\text { PC } \%(95 \% \mathrm{CI})\end{array}$ & $\begin{array}{l}\text { Multi-pollutant model } \\
\text { PC\% }(95 \% \text { CI })\end{array}$ \\
\hline \multirow{6}{*}{$\begin{array}{l}\text { Attended } \\
\text { emergency } \\
\text { room }\end{array}$} & $\mathrm{PM}_{10}\left(\mu \mathrm{g} / \mathrm{m}^{3}\right)$ & 0 & $0.18(0.12,0.25)$ & $0.42(0.31,0.52)$ \\
\hline & $\mathrm{PM}_{2.5}\left(\mu \mathrm{g} / \mathrm{m}^{3}\right)$ & 0 & $0.15(0.02,0.28)$ & $-0.77(-0.97,-0.57)$ \\
\hline & $\mathrm{NO}_{2}\left(\mu \mathrm{g} / \mathrm{m}^{3}\right)$ & 0 & $0.46(0.05,0.87)$ & - \\
\hline & $\mathrm{O}_{3}\left(\mu \mathrm{g} / \mathrm{m}^{3}\right)$ & 3 & $-0.65(-1.11,0.19)$ & $-0.92(-1.31,-0.53)$ \\
\hline & $\mathrm{CO}\left(\mathrm{mg} / \mathrm{m}^{3}\right)$ & 2 & $13.19(0.10,27.99)$ & $18.35(9.01,28.48)$ \\
\hline & $\mathrm{SO}_{2}\left(\mu \mathrm{g} / \mathrm{m}^{3}\right)$ & 0 & $5.11(3.73,6.51)$ & $5.17(3.94,6.43)$ \\
\hline \multirow{5}{*}{$\begin{array}{l}\text { Visited } \\
\text { emergency } \\
\text { room } \\
\text { having } \\
\text { acute } \\
\text { respiratory } \\
\text { symptoms }\end{array}$} & $\mathrm{PM}_{10}\left(\mu \mathrm{g} / \mathrm{m}^{3}\right)$ & 0 & $0.33(0.16,0.51)$ & $-0.18(-0.32,-0.03)$ \\
\hline & $\mathrm{NO}_{2}\left(\mu \mathrm{g} / \mathrm{m}^{3}\right)$ & 1 & $1.31(0.12,2.51)$ & $1.07(0.32,1.83)$ \\
\hline & $\mathrm{O}_{3}\left(\mu \mathrm{g} / \mathrm{m}^{3}\right)$ & 3 & $-1.89(-3.11,-0.65)$ & $-4.16(-5.18,-3.13)$ \\
\hline & $\mathrm{CO}\left(\mathrm{mg} / \mathrm{m}^{3}\right)$ & 3 & $29.59(0.84,66.54)$ & $36.89(12.24,66.95)$ \\
\hline & $\mathrm{SO}_{2}\left(\mu \mathrm{g} / \mathrm{m}^{3}\right)$ & 0 & $10.45(6.84,14.18)$ & $12.77(9.51,16.12)$ \\
\hline \multirow{5}{*}{$\begin{array}{l}\text { Visited } \\
\text { emergency } \\
\text { room } \\
\text { having } \\
\text { cough }\end{array}$} & $\mathrm{PM}_{10}\left(\mu \mathrm{g} / \mathrm{m}^{3}\right)$ & 0 & $0.32(0.14,0.50)$ & - \\
\hline & $\mathrm{NO}_{2}\left(\mu \mathrm{g} / \mathrm{m}^{3}\right)$ & 1 & $1.9(0.7,3.11)$ & $2.10(1.04,3.16)$ \\
\hline & $\mathrm{O}_{3}\left(\mu \mathrm{g} / \mathrm{m}^{3}\right)$ & 2 & $-2.05(-3.48,-0.61)$ & $-4.97(-6.03,-3.89)$ \\
\hline & $\mathrm{CO}\left(\mathrm{mg} / \mathrm{m}^{3}\right)$ & 1 & $47.03(8.28,99.65)$ & - \\
\hline & $\mathrm{SO}_{2}\left(\mu \mathrm{g} / \mathrm{m}^{3}\right)$ & 0 & $9.08(5.46,12.82)$ & $11.99(8.7,15.38)$ \\
\hline \multirow{5}{*}{$\begin{array}{l}\text { Visited } \\
\text { emergency } \\
\text { room } \\
\text { having } \\
\text { noisy } \\
\text { breathing }\end{array}$} & $\mathrm{PM}_{10}\left(\mu \mathrm{g} / \mathrm{m}^{3}\right)$ & 2 & $0.28(-0.01,0.56)$ & - \\
\hline & $\mathrm{PM}_{2.5}\left(\mu \mathrm{g} / \mathrm{m}^{3}\right)$ & 3 & $-0.56(-0.98,-0.14)$ & - \\
\hline & $\mathrm{NO}_{2}\left(\mu \mathrm{g} / \mathrm{m}^{3}\right)$ & 1 & $-2.38(-3.63,-1.12)$ & $-1.84(-2.85,-0.82)$ \\
\hline & $\mathrm{O}_{3}\left(\mu \mathrm{g} / \mathrm{m}^{3}\right)$ & 3 & $-4.40(-6.00,-2.78)$ & $-4.63(-6.01,-3.22)$ \\
\hline & $\mathrm{SO}_{2}\left(\mu \mathrm{g} / \mathrm{m}^{3}\right)$ & 1 & $6.90(1.77,12.28)$ & $11.60(7.66,15.68)$ \\
\hline \multirow{6}{*}{$\begin{array}{l}\text { Visited } \\
\text { emergency } \\
\text { room } \\
\text { having } \\
\text { difficulty in } \\
\text { breathing }\end{array}$} & $\mathrm{PM}_{10}\left(\mu \mathrm{g} / \mathrm{m}^{3}\right)$ & 0 & $0.47(0.28,0.66)$ & $0.59(0.26,0.91)$ \\
\hline & $\mathrm{PM}_{2.5}\left(\mu \mathrm{g} / \mathrm{m}^{3}\right)$ & 0 & $0.54(0.19,0.89)$ & $-1.12(-1.71,3.38)$ \\
\hline & $\mathrm{NO}_{2}\left(\mu \mathrm{g} / \mathrm{m}^{3}\right)$ & 1 & $2.33(1.08,3.60)$ & $2.27(1.17,3.38)$ \\
\hline & $\mathrm{O}_{3}\left(\mu \mathrm{g} / \mathrm{m}^{3}\right)$ & 3 & $-3.39(-4.73,-2.03)$ & $-4.51(-5.63,-3.38)$ \\
\hline & $\mathrm{CO}\left(\mathrm{mg} / \mathrm{m}^{3}\right)$ & 1 & $47.45(6.59,103.96)$ & - \\
\hline & $\mathrm{SO}_{2}\left(\mu \mathrm{g} / \mathrm{m}^{3}\right)$ & 0 & $7.75(3.89,11.75)$ & $10.64(7.16,14.23)$ \\
\hline \multirow{6}{*}{$\begin{array}{l}\text { Visited } \\
\text { emergency } \\
\text { room } \\
\text { having } \\
\text { nasal } \\
\text { symptoms }\end{array}$} & $\mathrm{PM}_{10}\left(\mu \mathrm{g} / \mathrm{m}^{3}\right)$ & 0 & $0.43(0.25,0.62)$ & $0.95(0.64,1.27)$ \\
\hline & $\mathrm{PM}_{2.5}\left(\mu \mathrm{g} / \mathrm{m}^{3}\right)$ & 0 & $0.39(0.04,0.75)$ & $-1.69(-2.28,-1.11)$ \\
\hline & $\mathrm{NO}_{2}\left(\mu \mathrm{g} / \mathrm{m}^{3}\right)$ & 1 & $2.28(1.01,3.56)$ & $2.08(0.95,3.22)$ \\
\hline & $\mathrm{O}_{3}\left(\mu \mathrm{g} / \mathrm{m}^{3}\right)$ & 0 & $-1.48(-2.83,-0.11)$ & $-3.39(-4.6,-2.16)$ \\
\hline & $\mathrm{CO}\left(\mathrm{mg} / \mathrm{m}^{3}\right)$ & 1 & $62.01(16.59,125.13)$ & - \\
\hline & $\mathrm{SO}_{2}\left(\mu \mathrm{g} / \mathrm{m}^{3}\right)$ & 0 & $6.54(2.63,10.60)$ & $10.25(6.73,13.88)$ \\
\hline \multicolumn{5}{|c|}{$\begin{array}{l}\text { Data expressed as a percentage change (95\% Confidence Interval). Statistically significant results } \\
\text { p }<0.05 \text { are presented. }\end{array}$} \\
\hline \multicolumn{5}{|c|}{$\begin{array}{l}\text { *Highest percentage change in emergency visits of children estimated from the single-pollutant model at at } \\
\text { a single lag day after accounting for the average daily temperature, relative humidity, days of the week } \\
\text { and public holidays. } \\
\text { "Estimates from multi-pollutant models containing various pollutants simultaneously. }\end{array}$} \\
\hline \multicolumn{5}{|c|}{$\begin{array}{l}\text { Abbreviations: PM-particulate matter, } \mathrm{NO}_{2} \text {-nitrogen dioxide, } \mathrm{O}_{3} \text {-ozone, } \mathrm{CO} \text {-carbon monoxide, } \mathrm{SO}_{2-} \\
\text { sulfur dioxide. }\end{array}$} \\
\hline
\end{tabular}


medRxiv preprint doi: https://doi.org/10.1101/2020.11.17.20223701; this version posted November 19,2020 . The copyright holder for this preprint (which was not certified by peer review) is the author/funder, who has granted medRxiv a license to display the preprint in It is made available under a CC-BY-NC-ND 4.0 International license .

\subsection{Discussion}

The present study examined the acute effects of air pollution by measuring daily ERVs due to acute respiratory illnesses amongchildren at two general hospitals of Delhi over 21 months. Considering the cumulative effect of all the six ambient pollutants, results of cluster analysis suggest that the daily ER visits of children having acute respiratory symptoms is higher during high and moderate air pollution cluster days on the same day as compared with low pollution cluster days. The deleterious effect was found to be sustained, as there was an increase in the respiratory illness related ERVs even when the previous day1-6 of exposure to pollutants was taken into account.

Our study results concordant withthe previous studies conducted reporting a positive association between acute effects of air pollution and 1) counts of pediatric respiratory ER visits for children (Bono et al., 2016; C. A. Lin et al., 1999; Mansourian et al., 2010) and 2) increase in respiratory symptoms among asthmatic and non-asthmatic children (Preutthipan et al., 2004). Similar to our study findings, cluster analysis studies from Kanpur, India (H.-Y. Liu et al., 2013) and China (Qian et al., 2004) have shown that individuals in high air pollution exposure cluster regions are at greater risk of having respiratory symptoms and hospital visits. However, these studiesdid not consider time lags between air pollution and the incidence of respiratory morbidity, which was evaluated in the current study. We extended this analysis on a timescale, as high pollution regions might have low pollution days. Our analysis therefore, categorized days instead of the region and looked at the future association of ER visits. Children are more susceptible to adverse health effects of air pollution than adults due to immature lung growth vulnerable to inflammatory and oxidative damage (Kuo et al., 2019). Due to higher respiration rates, and outdoor physical activity, children retain a more considerable amount of air pollutants per unit body weight than adults (Bono et al., 2016). The adverse effects of acute exposure to air pollution on respiratory health in children may be due to decreases in pulmonary function, 
medRxiv preprint doi: https://doi.org/10.1101/2020.11.17.20223701; this version posted November 19,2020 . The copyright holder for this preprint (which was not certified by peer review) is the author/funder, who has granted medRxiv a license to display the preprint in It is made available under a CC-BY-NC-ND 4.0 International license .

increases in airway inflammation and oxidative stress (L. Liu et al., 2009).Various time-series studies(Bono et al., 2016; G. Chen, Li, et al., 2017; G. Chen, Zhang, et al., 2017; RodríguezVillamizar et al., 2018; Segala et al., 1998) have shown that any effect of air pollution may be concurrent or may last for several days after exposure to pollutants suggesting the persistence of airway inflammation and oxidative stress.

The multi-pollutant generalized additive model was carried outto examine the effect of exposure to individual pollutant levels on 0-3 day before the ER visit and their impact with other pollutants on ER visits for acute respiratory symptoms. All the air pollutants, i.e. $\mathrm{PM}_{10}, \mathrm{NO}_{2}, \mathrm{O}_{3}$, $\mathrm{CO}$ and $\mathrm{SO}_{2}$ showed independent effects except for $\mathrm{PM}_{2.5}$. In the present study, a $10 \mu \mathrm{g} / \mathrm{m}^{3}$ increase $\mathrm{PM}_{10}$ was positively associated with $0.33 \%(0.16,0.51)$ increase in acute respiratory ER visits in the single-pollutant model, which is consistent with the earlier reports (Lee et al., 2006; C. A. Lin et al., 1999; Preutthipan et al., 2004; Rodríguez-Villamizar et al., 2018). However, in the multi-pollutant model, $\mathrm{PM}_{10}$, despite having higher levels, were associated negatively with acute ER visits of children. It might be possible that during high pollution days, people try to reduce their exposure levels by staying at home, wearing masks, using air purifier etc.(R. Chen et al., 2017) thus lowering the ER visit number. The other factors that affect the degree of associations of pollutants involve average concentrations of pollutants (Lu et al., 2019), heterogeneous composition of particulate matter and gaseous mixture varying with seasons, and age and gender of the exposed population (Rodríguez-Villamizar et al., 2018; Song et al., 2018). Several studies have shown that with an increase in $\mathrm{NO}_{2}, \mathrm{CO}$ and $\mathrm{SO}_{2}$, there is a significant percentage increase in ER visits for respiratory diseases in children (Sunyer et al., 1997; Lee et al., 2006; Canova et al., 2010; Rodríguez-Villamizar et al., 2018). $\mathrm{NO}_{2}$ is an indicator of traffic-related air pollution emitted by vehicle exhaust (R. Chen et al., 2017; Sunyer et al., 1997). In the present study, $10 \mu \mathrm{g} / \mathrm{m}^{3}$ increase in $\mathrm{NO}_{2}$ showed delayed effect and was associated with $1.07 \%(0.32,1.83)$ increase in acute respiratory ER visits on previous day 1 of 
medRxiv preprint doi: https://doi.org/10.1101/2020.11.17.20223701; this version posted November 19,2020 . The copyright holder for this preprint (which was not certified by peer review) is the author/funder, who has granted medRxiv a license to display the preprint in It is made available under a CC-BY-NC-ND 4.0 International license .

exposure to $\mathrm{NO}_{2}$. Similar findings have been documented in the earlier studies (Bono et al., 2016; Rodríguez-Villamizar et al., 2018) suggesting that most of the time patient try to manage symptoms at home, which causes a delay between the onset of respiratory symptoms due to pollutant and patient reaching ER (Cassino et al., 1999).

In contrast, a $10 \mu \mathrm{g} / \mathrm{m}^{3}$ increase in $\mathrm{SO}_{2}$ concentrations showed an immediate effect on the same day associated with $12.77 \%(9.51,16.12)$ increase in acute respiratory ER visits of children, which is in agreement with several other studies (Jaakkola et al., 1991; Kumar et al., 2007; Kuo et al., 2019; Pande et al., 2002; von Mutius et al., 1995). $\mathrm{SO}_{2}$ is emitted by industrial sources, domestic fuel burning and vehicles (H.-Y. Liu et al., 2013) and is a well-known immediate irritant causing inflammation of respiratory tract (Mansourian et al., 2010). For every $10 \mathrm{mg} / \mathrm{m}^{3}$ increase in $\mathrm{CO}$ concentrations on previous day 3 of ER visit was associated with a $36.89 \%$ $(12.24,66.95)$ increase in respiratory ER visits of enrolled children. This result is in concordance with previous studies showing an association of CO with ER visits (Canova et al., 2010; Villeneuve et al., 2007). CO is produced from incompletely combusted products (FINALREPORT_AQI_.Pdf, n.d.) and is postulated to exert its effect by acting as a surrogate for particulate matter (M. Lin et al., 2003). In our study period, the median concentrations of $\mathrm{SO}_{2}$ and $\mathrm{CO}$ were below permissible levels as per INAQS for the majority of the days but still showed a positive association with respiratory ER visits of children. This observation is in line with that reported in western countries (Jaakkola et al., 1991; M. Lin et al., 2003; Segala et al., 1998) in children with pre-existing chronic conditions leading to an increase in respiratory symptoms and deterioration of lung function (Jaakkola et al., 1991; Mansourian et al., 2010; Segala et al., 1998). $\mathrm{O}_{3}$ showed an independent negative association with acute respiratory ER on the same day as reported in earlier study (Tian et al., 2018). This lower effect of $\mathrm{O}_{3}$ during higher $\mathrm{O}_{3}$ levels could be attributed to the scavenging effects of $\mathrm{O}_{3}$ by the production of nitric oxide by roadside traffic (Bono et al., 2016), thereby leading to the reduced effect of $\mathrm{O}_{3}$ than that 
medRxiv preprint doi: https://doi.org/10.1101/2020.11.17.20223701; this version posted November 19,2020 . The copyright holder for this preprint (which was not certified by peer review) is the author/funder, who has granted medRxiv a license to display the preprint in It is made available under a CC-BY-NC-ND 4.0 International license .

of $\mathrm{PM}_{10}$ and $\mathrm{NO}_{2}$ (R. Chen et al., 2017). Alternatively, the individuals predisposed to $\mathrm{O}_{3}$ might develop respiratory symptoms at lower concentrations and reaches the hospital before $\mathrm{O}_{3}$ levels reach higher levels leading to the high effect of $\mathrm{O}_{3}$ at lower concentration (Tian et al., 2018).

There are several limitations to our study. We used air quality data from four stationary air quality monitoring stations to represent personal exposures that may induce measurement error. Data for respiratory ER visits and ambient air quality was collected for over 1.7 years, which is often small and might limit the power of the study. Therefore, to have more accurate results, it would be helpful to carry out these studies for a longer duration, including more hospitals from every part of Delhi.

The study also has important strengths. This is the first time-series study reporting the acute effects of ambient air pollution on acute respiratory symptoms in children of Delhi. Statistical analysis was performed using a time-series analysis that provides more robust estimations (Maji et al., 2018; Rodríguez-Villamizar et al., 2018). We used a multi-pollutant model to distinguish the role of multiple pollutants taking into account day to day variations, temperature, and humidity. Such multi-pollutant modelling in time-series epidemiologic studies of acute respiratory outcomes concerning ambient air pollution is limited (Tolbert et al., 2007).We studied the health effects of 6 major pollutants mixture reflecting the ambient air pollution in contrast to the studies where the effect of only particulate matter or few pollutants were seen $(\mathrm{G}$. Chen, Li, et al., 2017; Khan et al., 2019, p. 2; Kumar et al., 2007, p. 2; Linares \& Diaz, 2010; Pande et al., 2002; Preutthipan et al., 2004). Preliminary findings from this study emphasize that specific policies can be made and measures can be taken to handle the increased number of children with acute respiratory problems to ER during bad air quality days. An accurate prediction can be made so that diseased children can be informed about the vulnerable effects of individual air pollutants. Long-term studies are warranted to explore the particular effect of pollutants on specific disease conditions, individual variation in exposure to local air pollution 
medRxiv preprint doi: https://doi.org/10.1101/2020.11.17.20223701; this version posted November 19, 2020. The copyright holder for this preprint (which was not certified by peer review) is the author/funder, who has granted medRxiv a license to display the preprint in It is made available under a CC-BY-NC-ND 4.0 International license.

and the impact of air pollution on outpatient visits of children with chronic respiratory diseases. Additional work related to plausible biological mechanisms involved in long-term exposure of air pollution in children with respiratory disease is needed.

\subsection{Conclusion}

In the present study, we observed that short-term exposure to ambient air pollution is associated with an increase in daily ER visits of children for acute respiratory symptoms.

\section{Acknowledgements}

This task force project has been funded by Indian Council for Medical Research. We thank Mrs. Anumita Roy Chaudhry, from Centre for Science and Environment and Dr Arvind Pandey their valuable suggestions in this study.

Funding: This work was supported by the Indian Council of Medical Research, New Delhi India.

\section{Declaration of Competing Interest}

The authors declare that they have no conflict of interest and there is no financial disclosure to report in this paper.

\section{Authorship contribution statement}

Rashmi Yadav: Data curation; Investigation; Methodology; Project administration, Validation, Visualization, Roles/Writing - original draft. Aditya Nagori: Formal analysis, Software, Writing review \& editing. Aparna Mukherjee: Formal analysis, Methodology, Software, Supervision, Writing - review andediting. Varinder Singh: Conceptualization, Data curation, Investigation, Methodology, Project administration, Supervision, Writing - review \& editing. Geetika Yadav: Conceptualization, Project administration, and Visualization. Karan Madan: Project administration, Supervision, Writing - review \& editing. Randeep Guleria: Project administration, Supervision and Writing - review \& editing. Raj Kumar: Methodology, Data curation, Supervision. Parul Mrigpuri: Methodology, Data curation. Rohit Sarin: Methodology, Formal analysis, Supervision, Writing - review \& editing. Jitendra Kumar Saini: Methodology, Formal analysis, Writing - review \& editing. Kamal Singhal: Methodology, Data curation. Kana 
medRxiv preprint doi: https://doi.org/10.1101/2020.11.17.20223701; this version posted November 19,2020 . The copyright holder for this preprint (which was not certified by peer review) is the author/funder, who has granted medRxiv a license to display the preprint in It is made available under a CC-BY-NC-ND 4.0 International license .

Ram Jat: Methodology, Data curation. Rakesh Lodha: Conceptualization, Data curation, Formal analysis, Funding acquisition, Investigation, Methodology, Project administration, Supervision, Validation, Visualization and Writing - review \& editing. Rupinder Singh Dhaliwal: Resources; Conceptualization, Funding acquisition and Visualization. Mohan P George: Data curation and Methodology, Investigation. Sushil Kumar Kabra: Conceptualization, Data curation, Formal analysis, Funding acquisition, Investigation, Methodology,Project administration, Supervision, Validation, Visualization and Writing - review \& editing. R M Pandey and M Kalaivani: Formal analysis.

\section{References}

Agarwal, R., Jayaraman, G., Anand, S., \& Marimuthu, P. (2006). Assessing respiratory morbidity through pollution status and meteorological conditions for Delhi. Environmental Monitoring and Assessment, 114(1-3), 489-504. https://doi.org/10.1007/s10661-006-4935-3

Babin, S. M., Burkom, H. S., Holtry, R. S., Tabernero, N. R., Stokes, L. D., Davies-Cole, J. O., DeHaan, K., \& Lee, D. H. (2007). Pediatric patient asthma-related emergency department visits and admissions in Washington, DC, from 2001-2004, and associations with air quality, socio-economic status and age group. Environmental Health, 6, 9. https://doi.org/10.1186/1476-069X-6-9

Balakrishnan, K., Ganguli, B., Ghosh, S., Sankar, S., Thanasekaraan, V., Rayudu, V. N., Caussy, H., \& HEI Health Review Committee. (2011). Part 1. Short-term effects of air pollution on mortality: Results from a time-series analysis in Chennai, India. Research Report (HealthEffectsInstitute), 157, 7-44.

Bono, R., Romanazzi, V., Bellisario, V., Tassinari, R., Trucco, G., Urbino, A., Cassardo, C., Siniscalco, C., Marchetti, P., \& Marcon, A. (2016). Air pollution, aeroallergens and admissions to pediatric emergency room for respiratory reasons in Turin, northwestern Italy. BMC Public Health, 16. https://doi.org/10.1186/s12889-016-3376-3 
medRxiv preprint doi: https://doi.org/10.1101/2020.11.17.20223701; this version posted November 19,2020 . The copyright holder for this preprint (which was not certified by peer review) is the author/funder, who has granted medRxiv a license to display the preprint in It is made available under a CC-BY-NC-ND 4.0 International license .

Canova, C., Torresan, S., Simonato, L., Scapellato, M. L., Tessari, R., Visentin, A., Lotti, M., \& Maestrelli, P. (2010). Carbon monoxide pollution is associated with decreased lung function in asthmatic adults. European Respiratory Journal, 35(2), 266-272. https://doi.org/10.1183/09031936.00043709

Cassino, C., Ito, K., Bader, I., Ciotoli, C., Thurston, G., \& Reibman, J. (1999). Cigarette smoking and ozone-associated emergency department use for asthma by adults in New York City. American Journal of Respiratory and Critical Care Medicine, 159(6), 17731779. https://doi.org/10.1164/ajrccm.159.6.9809042

Chen, G., Li, S., Zhang, Y., Zhang, W., Li, D., Wei, X., He, Y., Bell, M. L., Williams, G., Marks, G. B., Jalaludin, B., Abramson, M. J., \& Guo, Y. (2017). Effects of ambient PM1 air pollution on daily emergency hospital visits in China: An epidemiological study. The Lancet. Planetary Health, 1(6), e221-e229. https://doi.org/10.1016/S25425196(17)30100-6

Chen, G., Zhang, Y., Zhang, W., Li, S., Williams, G., Marks, G. B., Jalaludin, B., Abramson, M. J., Luo, F., Yang, D., Su, X., Lin, Q., Liu, L., Lin, J., \& Guo, Y. (2017). Attributable risks of emergency hospital visits due to air pollutants in China: A multi-city study. Environmental Pollution (Barking, Essex: 1987), 228, 43-49. https://doi.org/10.1016/j.envpol.2017.05.026

Chen, H., \& Goldberg, M. S. (2009). The effects of outdoor air pollution on chronic illnesses. McGill Journal of Medicine : MJM, 12(1), 58-64.

Chen, R., Huang, W., Wong, C.-M., Wang, Z., Thach, T. Q., Chen, B., Kan, H., \& CAPES Collaborative Group. (2012). Short-term exposure to sulfur dioxide and daily mortality in 17 Chinese cities: The China air pollution and health effects study (CAPES). Environmental Research, 118, 101-106. https://doi.org/10.1016/j.envres.2012.07.003

Chen, R., Yin, P., Meng, X., Liu, C., Wang, L., Xu, X., Ross, J. A., Tse, L. A., Zhao, Z., Kan, H., \& Zhou, M. (2017). Fine Particulate Air Pollution and Daily Mortality. A Nationwide 
medRxiv preprint doi: https://doi.org/10.1101/2020.11.17.20223701; this version posted November $19,2020$. The copyright holder for this preprint (which was not certified by peer review) is the author/funder, who has granted medRxiv a license to display the preprint in It is made available under a CC-BY-NC-ND 4.0 International license .

Analysis in 272 Chinese Cities. American Journal of Respiratory and Critical Care Medicine, 196(1), 73-81. https://doi.org/10.1164/rccm.201609-1862OC

Chen, Z., Salam, M. T., Eckel, S. P., Breton, C. V., \&Gilliland, F. D. (2015). Chronic effects of air pollution on respiratory health in Southern California children: Findings from the Southern California Children's Health Study. Journal of Thoracic Disease, 7(1), 46-58. https://doi.org/10.3978/j.issn.2072-1439.2014.12.20

Cropper, M. L., Simon, N. B., Alberini, A., Arora, S., \& Sharma, P. K. (1997). The health benefits of air pollution control in Delhi. American Journal of Agricultural Economics, 79(5), 1625-1629.

Darrow, L. A., Klein, M., Flanders, W. D., Mulholland, J. A., Tolbert, P. E., \& Strickland, M. J. (2014). Air Pollution and Acute Respiratory Infections Among Children 0-4 Years of Age: An 18-Year Time-Series Study. American Journal of Epidemiology, 180(10), 968977. https://doi.org/10.1093/aje/kwu234

FINAL-REPORT_AQI_.pdf. (n.d.). Retrieved April 6, 2020, from https://app.cpcbccr.com/ccr_docs/FINAL-REPORT_AQI_.pdf

India State-Level Disease Burden Initiative Air Pollution Collaborators. (2018). The impact of air pollution on deaths, disease burden, and life expectancy across the states of India: The Global Burden of Disease Study 2017. The Lancet. Planetary Health. https://doi.org/10.1016/S2542-5196(18)30261-4

Jaakkola, J. J., Paunio, M., Virtanen, M., \& Heinonen, O. P. (1991). Low-level air pollution and upper respiratory infections in children. American Journal of Public Health, 81(8), 10601063.

Jayaraman, G., \& Nidhi, null. (2008). Air pollution and associated respiratory morbidity in Delhi. Health Care Management Science, 11(2), 132-138. 
medRxiv preprint doi: https://doi.org/10.1101/2020.11.17.20223701; this version posted November 19,2020 . The copyright holder for this preprint (which was not certified by peer review) is the author/funder, who has granted medRxiv a license to display the preprint in It is made available under a CC-BY-NC-ND 4.0 International license .

Jin, X., \& Han, J. (2010). K-Means Clustering. In C. Sammut \& G. I. Webb (Eds.), Encyclopedia of Machine Learning (pp. 563-564). Springer US. https://doi.org/10.1007/978-0-387-30164-8_425

Kesavachandran, C. N., Bihari, V., Pangtey, B. S., Kamal, R., Singh, A., \& Srivastava, A. K. (2015). Gender Disparity in Lung Function Abnormalities among a Population Exposed to Particulate Matter Concentration in Ambient Air in the National Capital Region, India. Journal of Health \& Pollution, 5(9), 47-60. https://doi.org/10.5696/2156-9614-5-9.47

Khan, R., Konishi, S., Ng, C. F. S., Umezaki, M., Kabir, A. F., Tasmin, S., \& Watanabe, C. (2019). Association between short-term exposure to fine particulate matter and daily emergency room visits at a cardiovascular hospital in Dhaka, Bangladesh. The Science of the Total Environment, 646, 1030-1036. https://doi.org/10.1016/j.scitotenv.2018.07.288

Khilnani, G. C., \&Tiwari, P. (2018). Air pollution in India and related adverse respiratory health effects: Past, present, and future directions. Current Opinion in Pulmonary Medicine, 24(2), 108-116. https://doi.org/10.1097/MCP.0000000000000463

Kumar, R., Nagar, J. K., Kumar, H., Kushwah, A. S., Meena, M., Kumar, P., Raj, N., Singhal, M. K., \& Gaur, S. N. (2007). Association of indoor and outdoor air pollutant level with respiratory problems among children in an industrial area of Delhi, India. Archives of Environmental \& Occupational Health, 62(2), 75-80. https://doi.org/10.3200/AEOH.62.2.75-80

Kuo, C.-Y., Chan, C.-K., Wu, C.-Y., Phan, D.-V., \& Chan, C.-L. (2019). The Short-Term Effects of Ambient Air Pollutants on Childhood Asthma Hospitalization in Taiwan: A National Study. International Journal of Environmental Research and Public Health, 16(2). https://doi.org/10.3390/ijerph16020203

Lee, S. L., Wong, W. H. S., \& Lau, Y. L. (2006). Association between air pollution and asthma admission among children in Hong Kong. Clinical and Experimental Allergy: Journal of 
medRxiv preprint doi: https://doi.org/10.1101/2020.11.17.20223701; this version posted November 19,2020 . The copyright holder for this preprint (which was not certified by peer review) is the author/funder, who has granted medRxiv a license to display the preprint in It is made available under a CC-BY-NC-ND 4.0 International license .

the British Society for Allergy and Clinical Immunology, 36(9), 1138-1146. https://doi.org/10.1111/j.1365-2222.2006.02555.x

Lin, C. A., Martins, M. A., Farhat, S. C., Pope, C. A., Conceição, G. M., Anastácio, V. M., Hatanaka, M., Andrade, W. C., Hamaue, W. R., Böhm, G. M., \& Saldiva, P. H. (1999). Air pollution and respiratory illness of children in São Paulo, Brazil. Paediatric and Perinatal Epidemiology, 13(4), 475-488. https://doi.org/10.1046/j.13653016.1999.00210.x

Lin, M., Chen, Y., Burnett, R., Villeneuve, P., \& Krewski, D. (2003). Effect of short-term exposure to gaseous pollution on asthma hospitalisation in children: A bi-directional case-crossover analysis. Journal of Epidemiology and Community Health, 57(1), 50-55. https://doi.org/10.1136/jech.57.1.50

Linares, C., \& Diaz, J. (2010). Short-term effect of $\operatorname{PM(2.5)~on~daily~hospital~admissions~in~}$ Madrid (2003-2005). International Journal of Environmental Health Research, 20(2), 129-140. https://doi.org/10.1080/09603120903456810

Liu, H.-Y., Bartonova, A., Schindler, M., Sharma, M., Behera, S. N., Katiyar, K., \& Dikshit, O. (2013). Respiratory Disease in Relation to Outdoor Air Pollution in Kanpur, India. Archives of Environmental \& Occupational Health, 68(4), 204. https://doi.org/10.1080/19338244.2012.701246

Liu, L., Poon, R., Chen, L., Frescura, A.-M., Montuschi, P., Ciabattoni, G., Wheeler, A., \& Dales, R. (2009). Acute effects of air pollution on pulmonary function, airway inflammation, and oxidative stress in asthmatic children. Environmental Health Perspectives, 117(4), 668-674. https://doi.org/10.1289/ehp11813

Lu, P., Zhang, Y., Lin, J., Xia, G., Zhang, W., Knibbs, L. D., Morgan, G. G., Jalaludin, B., Marks, G., Abramson, M., Li, S., \& Guo, Y. (2019). Multi-city study on air pollution and hospital outpatient visits for asthma in China. Environmental Pollution (Barking, Essex: 1987), 113638. https://doi.org/10.1016/j.envpol.2019.113638 
medRxiv preprint doi: https://doi.org/10.1101/2020.11.17.20223701; this version posted November 19,2020 . The copyright holder for this preprint (which was not certified by peer review) is the author/funder, who has granted medRxiv a license to display the preprint in It is made available under a CC-BY-NC-ND 4.0 International license .

Maji, S., Ahmed, S., Siddiqui, W. A., \& Ghosh, S. (2017). Short term effects of criteria air pollutants on daily mortality in Delhi, India. Atmospheric Environment, 150, 210-219. https://doi.org/10.1016/j.atmosenv.2016.11.044

Maji, S., Ghosh, S., \& Ahmed, S. (2018). Association of air quality with respiratory and cardiovascular morbidity rate in Delhi, India. International Journal of Environmental Health Research, 28(5), 471-490. https://doi.org/10.1080/09603123.2018.1487045

Mansourian, M., Javanmard, S. H., Poursafa, P., \& Kelishadi, R. (2010). Air Pollution and Hospitalization for Respiratory Diseases Among Children in Isfahan, Iran. Ghana Medical Journal, 44(4), 138-143.

Pande, J. N., Bhatta, N., Biswas, D., Pandey, R. M., Ahluwalia, G., Siddaramaiah, N. H., \& Khilnani, G. C. (2002). Outdoor air pollution and emergency room visits at a hospital in Delhi. Indian Journal of Chest Diseases and Allied Sciences, 44(1), 13-20.

Preutthipan, A., Udomsubpayakul, U., Chaisupamongkollarp, T., \& Pentamwa, P. (2004). Effect of PM10 pollution in Bangkok on children with and without asthma. Pediatric Pulmonology, 37(3), 187-192. https://doi.org/10.1002/ppul.10398

Qian, Z., Chapman, R. S., Hu, W., Wei, F., Korn, L. R., \& Zhang, J. (Jim). (2004). Using air pollution based community clusters to explore air pollution health effects in children. Environment International, 30(5), 611-620. https://doi.org/10.1016/j.envint.2003.11.003

$R$ : The R Project for Statistical Computing. (n.d.). Retrieved May 11, 2020, from https://www.rproject.org/

Rajarathnam, U., Sehgal, M., Nairy, S., Patnayak, R. C., Chhabra, S. K., Kilnani, null, Ragavan, K. V. S., \& HEI Health Review Committee. (2011). Part 2. Time-series study on air pollution and mortality in Delhi. Research Report (Health Effects Institute), 157, 47-74.

Rodríguez-Villamizar, L. A., Rojas-Roa, N. Y., Blanco-Becerra, L. C., Herrera-Galindo, V. M., \& Fernández-Niño, J. A. (2018). Short-Term Effects of Air Pollution on Respiratory and Circulatory Morbidity in Colombia 2011²014: A Multi-City, Time-Series Analysis. 
medRxiv preprint doi: https://doi.org/10.1101/2020.11.17.20223701; this version posted November 19,2020 . The copyright holder for this preprint (which was not certified by peer review) is the author/funder, who has granted medRxiv a license to display the preprint in It is made available under a CC-BY-NC-ND 4.0 International license .

International Journal of Environmental Research and Public Health, 15(8). https://doi.org/10.3390/ijerph15081610

Segala, C., Fauroux, B., Just, J., Pascual, L., Grimfeld, A., \& Neukirch, F. (1998). Short-term effect of winter air pollution on respiratory health of asthmatic children in Paris. European Respiratory Journal, 11(3), 677-685.

Sinha, A., Desiraju, K., Aggarwal, K., Kutum, R., Roy, S., Lodha, R., Kabra, S. K., Ghosh, B., Sethi, T., \& Agrawal, A. (2017). Exhaled breath condensate metabolome clusters for endotype discovery in asthma. Journal of Translational Medicine, 15(1), 262. https://doi.org/10.1186/s12967-017-1365-7

Song, J., Lu, M., Zheng, L., Liu, Y., Xu, P., Li, Y., Xu, D., \& Wu, W. (2018). Acute effects of ambient air pollution on outpatient children with respiratory diseases in Shijiazhuang, China. BMC Pulmonary Medicine, 18(1), 150. https://doi.org/10.1186/s12890-018-07163

Sunyer, J., Spix, C., Quénel, P., Ponce-de-León, A., Pönka, A., Barumandzadeh, T., Touloumi, G., Bacharova, L., Wojtyniak, B., Vonk, J., Bisanti, L., Schwartz, J., \& Katsouyanni, K. (1997). Urban air pollution and emergency admissions for asthma in four European cities: The APHEA Project. Thorax, 52(9), 760-765. https://doi.org/10.1136/thx.52.9.760

Tapia, V., Steenland, K., Sarnat, S. E., Vu, B., Liu, Y., Sánchez-Ccoyllo, O., Vasquez, V., \& Gonzales, G. F. (2019). Time-series analysis of ambient PM2.5 and cardiorespiratory emergency room visits in Lima, Peru during 2010-2016. Journal of Exposure Science \& Environmental Epidemiology. https://doi.org/10.1038/s41370-019-0189-3

Tian, Y., Xiang, X., Juan, J., Song, J., Cao, Y., Huang, C., Li, M., \& Hu, Y. (2018). Short-term Effect of Ambient Ozone on Daily Emergency Room Visits in Beijing, China. Scientific Reports, 8(1), 2775. https://doi.org/10.1038/s41598-018-21154-x

Tolbert, P. E., Klein, M., Peel, J. L., Sarnat, S. E., \& Sarnat, J. A. (2007). Multipollutant modeling issues in a study of ambient air quality and emergency department visits in 
medRxiv preprint doi: https://doi.org/10.1101/2020.11.17.20223701; this version posted November 19, 2020. The copyright holder for this preprint (which was not certified by peer review) is the author/funder, who has granted medRxiv a license to display the preprint in It is made available under a CC-BY-NC-ND 4.0 International license .

Atlanta. Journal of Exposure Science \& Environmental Epidemiology, 17 Suppl 2, S2935. https://doi.org/10.1038/sj.jes.7500625

Villeneuve, P. J., Chen, L., Rowe, B. H., \& Coates, F. (2007). Outdoor air pollution and emergency department visits for asthma among children and adults: A case-crossover study in northern Alberta, Canada. Environmental Health, 6, 40. https://doi.org/10.1186/1476-069X-6-40

von Mutius, E., Sherrill, D. L., Fritzsch, C., Martinez, F. D., \& Lebowitz, M. D. (1995). Air pollution and upper respiratory symptoms in children from East Germany. The European Respiratory Journal, 8(5), 723-728. 